\title{
sciendo

\section{Is the High Quality Baukultur a Monkey Wrench in the Global Climate Challenges?}

\author{
Andra BLUMBERGA ${ }^{1 *}$, Ruta VANAGA ${ }^{2}$, Juris ANTUZS ${ }^{3}$, Ritvars FREIMANIS ${ }^{4}$, \\ Edgars BONDARS ${ }^{5}$, Sandra TREIJA ${ }^{6}$ \\ ${ }^{1-4}$ Institute of Energy Systems and Environment, Riga Technical University, Azenes iela 12/1, \\ Riga, LV-1048, Latvia \\ ${ }^{5-6}$ Faculty of Architecture, Riga Technical University, Kipsalas iela 6, Riga, LV-1048, Latvia
}

\begin{abstract}
The EU 2030 climate package calls for raising energy efficiency, increasing usage of RES and decreasing the carbon footprint. There are stringent requirements for new buildings, but the energy efficiency potential in the existing building stock is still not fully explored. The latest trend in urban energy efficiency is the Positive Energy Block (PEB) strategies for new developments. It includes raising building energy efficiency, optimizing energy flow and implementing renewable energy sources (RES). Transforming all existing blocks in a city centre to a PEB would radically change the pattern of energy supply and consumption. European cities have historic centres with great architectural and cultural value. Any urban regeneration strategies must respect and preserve historic values. This paper describes double multi-criteria analysis evaluating urban blocks from both the energy efficiency and cultural heritage perspective with the goal to select the sample block for a "Smart urban regeneration - transition to the Positive Energy Block" case study. Proposed criteria for multi-criteria analysis to evaluate cultural heritage, liveability and energy efficiency potential describes specific qualities of the urban block. The obtained results show that blocks with higher cultural value show less energy efficiency potential and vice versa. It is recommended to apply cultural value and liveability qualities in the Smart urban regeneration process to those blocks with high energy efficiency potential.
\end{abstract}

Keywords - Building energy efficiency; cultural heritage; Davos declaration; energy community; historic city centre; liveable city; multi-criteria analysis (MCA); Positive Energy Block (PEB); smart urban regeneration

\begin{tabular}{|ll}
\hline \multicolumn{2}{l}{ Nomenclature } \\
PEB & Positive energy block \\
MCA & Multi-criteria analysis \\
nZEB & Nearly Zero energy building \\
RHC & Riga Historic Centre \\
GHG & Greenhouse gases \\
\hline
\end{tabular}

* Corresponding author.

E-mail address: andra.blumberga@rtu.lv 


\section{INTRODUCTION}

\subsection{Climate Change Mitigation}

Frequent extreme weather occurrences, irreversible loss of biodiversity, animal species migrating to new habitats misbalancing local ecosystems, even humans are migrating or being displaced facing extreme weather or related scarce resources/nutrition are the effects of climate change we have to face. The climate change is present and very likely driven by anthropogenic impact (raising GHG levels due to human activities) [1]-[5]. To mitigate climate change, the Paris Agreement has set the goal to restrict anthropogenic impact on climate systems by decreasing GHG emissions and limiting global temperature increase to $1.5^{\circ} \mathrm{C}[6],[7]$.

The EU is fully committed to international climate mitigation goals and continually sets new targets for GHG reduction in climate policy packages developed by the European Climate Change Programme and each member state contributes to the common goal [8]. The 2030 climate and energy framework is currently in force and it aims to cut GHG, to increase the use of renewables and to raise energy efficiency [9].

\subsection{Dilemma - Building Energy Efficiency in Historic City Centre vs Preservation of Cultural Heritage}

Buildings and construction account for $36 \%$ of global final energy [10], cities account for around $75 \%$ of $\mathrm{CO}_{2}$ emissions from final energy use [11], [12] and this makes the building sector and urban areas a target of energy efficiency policies [13]-[16]. There are stringent requirements for new developments - all new buildings must be nearly zero energy buildings (nZEB) and the latest EU Directive 2018/844/EU stresses the necessity of reaching nearly zero energy building benchmarks in building renovations and decarbonizing the existing building stock.

There are a number of techniques developed for energy efficiency measures for buildings built in the post-WWII era. Thus pre-WWII buildings demand more skilled renovations, preserving possible cultural heritage values [17]-[19]. Especially in dense urban environments, new energy efficiency techniques for renovation of culturally valuable building stock are urgently necessary to fulfil the plans of decarbonising the existing building stock.

Energy efficiency driven refurbishment often is accused of not respecting the aesthetic needs and surrounding context and prioritizing technological and economic issues. To trigger changes in building processes and understanding of the importance of the built environment, Davos declaration (2018) calls to reinforce the traditions of high quality "Baukultur" and reminds us that the built environment is one of essential cultural values - it creates a scene for habitat and is essential to the quality of life. The Davos declaration emphasizes the importance of liveable surroundings and preservation of cultural values [20], [21]. On one hand there lies big energy efficiency potential in existing building stock, but on the other hand cultural values must be preserved. Will the Davos declaration requirements limit local and global energy efficiency and climate goals? To what extent? Is there a compromise possible?

Research project "Smart urban regeneration - transition from traditional urban block to the Positive Energy Block in Riga Historic Centre" will evaluate the possibilities and limits of energy efficiency driven smart urban regeneration in valuable historic environment. 


\subsection{Positive Energy Blocks}

Research launched matches to the European Strategic Energy Technology Plan (SET-Plan) aiming to reduce GHG emissions accelerating the deployment of low-carbon technologies and specifically addresses smart cities and communities as the target group by introducing positive energy blocks/districts [22]. In the scope of building a low-carbon, climate resilient future, the concept of smart cities has been developed to promote energy transition in cities "Positive Energy Blocks (PEB)/districts consist of several buildings (new, retro-fitted or a combination of both) that actively manage their energy consumption and the energy flow between them and the wider energy system. PEB/Districts have an annual positive energy balance. They make optimal use of elements such as advanced materials, local RES, local storage, smart energy grids, demand-response, cutting edge energy management (electricity, heating and cooling), user interaction/involvement and information and communications technologies (ICT)" [23], [24]. In a symbiotic approach combining all buildings within one block in a single energy system can be beneficial to every building unit and the overall building energy efficiency goals can be easier to achieve.

\subsection{Smart Urban Regeneration - Transition to a Positive Energy Block Respecting the High Quality of Baukultur}

The research has two equally important goals - to reach a positive yearly energy balance and to apply high quality Baukultur requirements to energy-driven, smart urban regeneration. The result of this research will demonstrate to what extent preservation of cultural values might limit energy efficiency goals. The first step of the study and the scope of this paper is the selection of Riga's Historic Centre urban block with the greatest potential to reach a positive yearly energy balance.

\section{Methodology OF THE StUdy}

Proposed methodology of selection of the urban block with the greatest potential to reach the positive yearly energy balance is applicable to any densely built urban environment.

The aim of the first step of the study is to select a RHC block for smart urban regeneration. Since there are two equally important goals for the study, the selection of the block is considered from two perspectives - its energy efficiency potential and the high quality Baukultur and liveability in urban blocks.

The selection of the block will be based on multi-criteria analysis (MCA) where possible alternatives are evaluated according to the set of criteria important for the goal [25], [26]. MCA has been used in numerous sustainable development studies [27]-[34].

Research is carried out in three phases (Fig. 1). In PHASE 1 - the decision-making context is identified, goals are set and a decision-making hierarchy is created. In PHASE 2 multiple sets of MCA are performed according to the number of stakeholders involved. In the scope of this research "Energy efficiency" and "Cultural heritage and liveability" are considered. The alternatives are ranked according to the sub-goals of each analysis, and the best alternative for each stakeholder is determined. In PHASE 3 results are compared and final decisions made based on PHASE 2 findings and summarized in conclusions. 


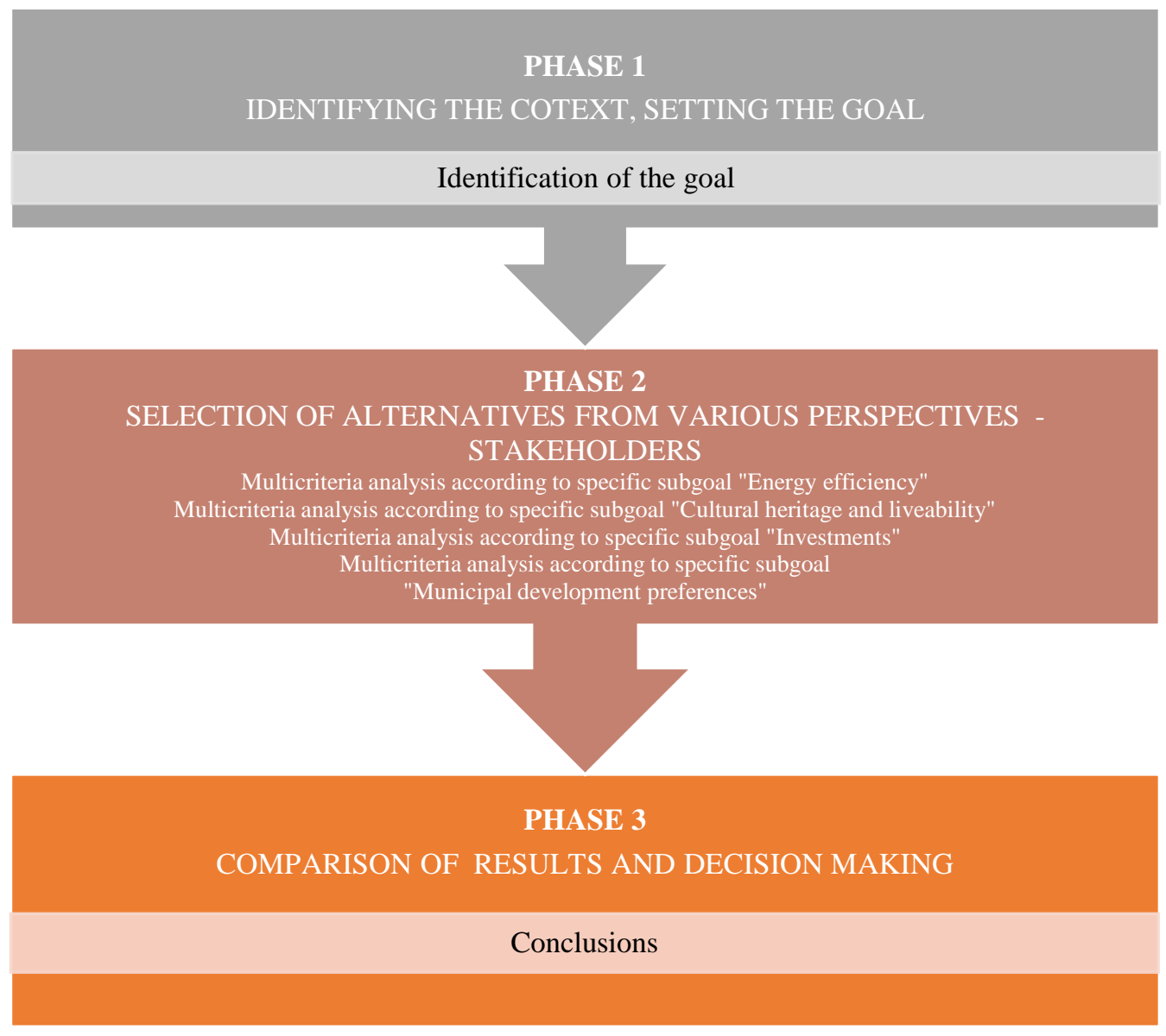

Fig. 1. Methodology of the study.

MCA is carried out in three steps. The $1^{\text {st }}$ step is to define outranking criteria that are essential for the goal, so the blocks missing essential criteria are excluded from further study. The $2^{\text {nd }}$ step is to define and weight criteria using Analytical Hierarchy Process methodology. In the $3^{\text {rd }}$ step TOPSIS is used for ranking the alternatives [25].

\section{Case Study: Urban Block Selection Riga Historic Centre for SMART URBAN REGENERATION}

\subsection{PHASE 1 - Identifying the Context, Setting the Goal}

Context. Fig. 2 illustrates the average age of buildings in Riga city [35]. The city centre comprises of the oldest buildings (more than 80 years), but the outskirts of the city are dominated by buildings of less than 50 years illustrating the expansion waves of Riga city. The launched study focusing on Historic Centre of Riga will provide new knowledge for energy efficiency driven intensive refurbishments in dense urban areas carrying cultural values. 

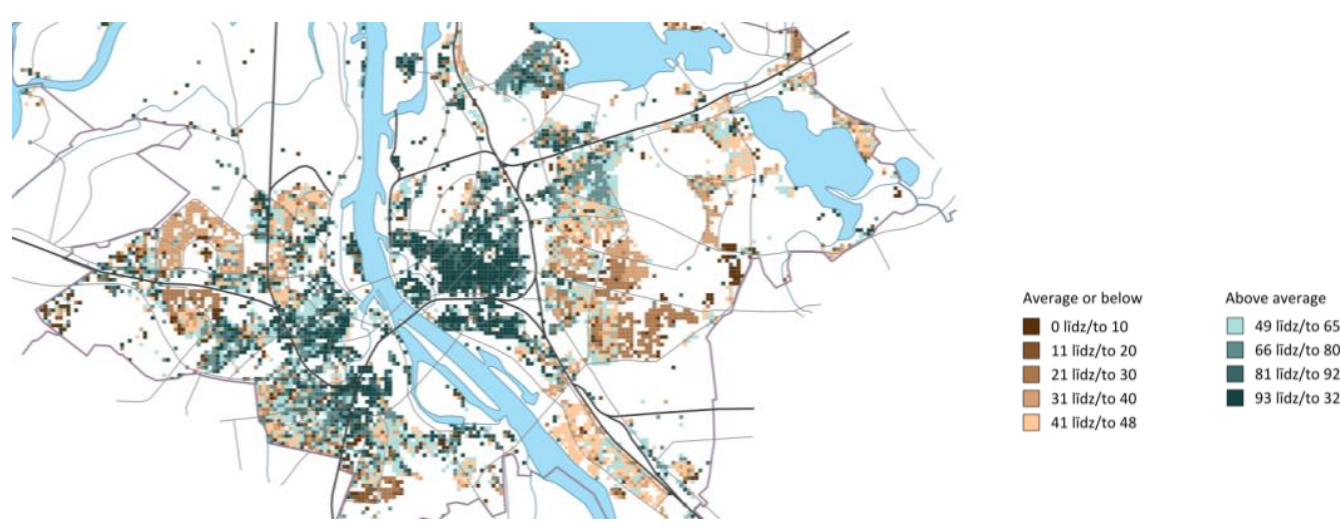

Fig. 2. Average age of inhabited dwellings in Riga [32].

The special value of the Riga Historic Centre RHC (Fig. 3) is its unique architecture - Art Nouveau buildings, wooden buildings and industrial architectural heritage. Historical values coexist with multifunctional use. RHC is a town-constructive monument with a unique landscape consisting of the multifunctional character of the city centre and its unique architecture. Preserving the cultural heritage while implementing the new developments to the historical environment is the vision set out in the "'Riga Sustainable Development Strategy 2030', [38].

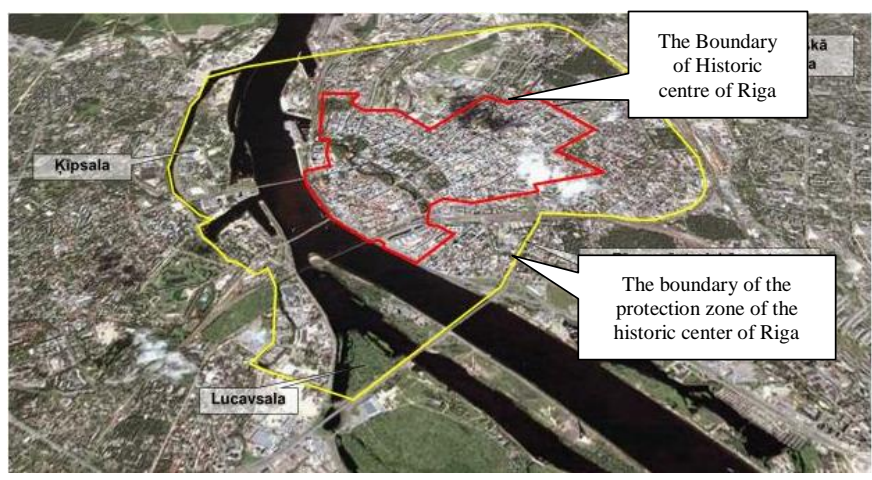

(a)

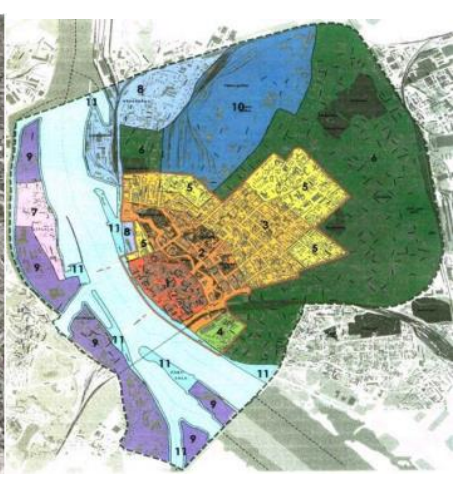

(b)

Fig. 3. (a) Riga Historic Centre in the context of the city [36]; (b) zoning in Riga Historic Centre and its protection zone [37].

The status of the UNESCO World Heritage Site [39], [40] puts the city of Riga in the context of global urban competition. The rich cultural background makes RHC a perfect scene for Smart urban regeneration - transition to a PEB respecting the high quality Baukultur.

The goal. The first step in the Smart urban regeneration research project is to select the RHC urban block that reflects energy efficiency capacities and high quality Baukultur and cultural heritage values.

The RHC and its protection zone are subdivided in 11 characteristic territories (Fig. 3(b)). This research is focusing on the densest territories of RHC - its core (No. 3) and the outer parts of the core (No. 5). The first screening of RHC shows that blocks with energy efficiency capacities are located at the outer perimeter of RHC, but blocks with higher cultural value are 
concentrated in the central parts of RHC, therefore two sub-goals are defined in decision making hierarchy 1) to find the RHC urban block with the highest energy efficiency potential and 2) to find the RHC urban block representing the highest qualities of cultural heritage and urban liveability.

\subsection{PHASE 2 - Selection of Alternatives from Various Perspectives}

\subsubsection{Multi-Criteria Analysis, Selecting the "Cultural Heritage Block"}

The unique values of RHC - listed buildings of national importance, Art Nouveau buildings and wooden buildings - are defined as the outranking criteria for further selection of "Cultural heritage block". Map overlay method [41], [42] was used in this step - colouring blocks comprising each outranking criterion. Blocks that comprise all three criteria are the subject of the next step of the evaluation process. 15 blocks were selected (Fig. 4).

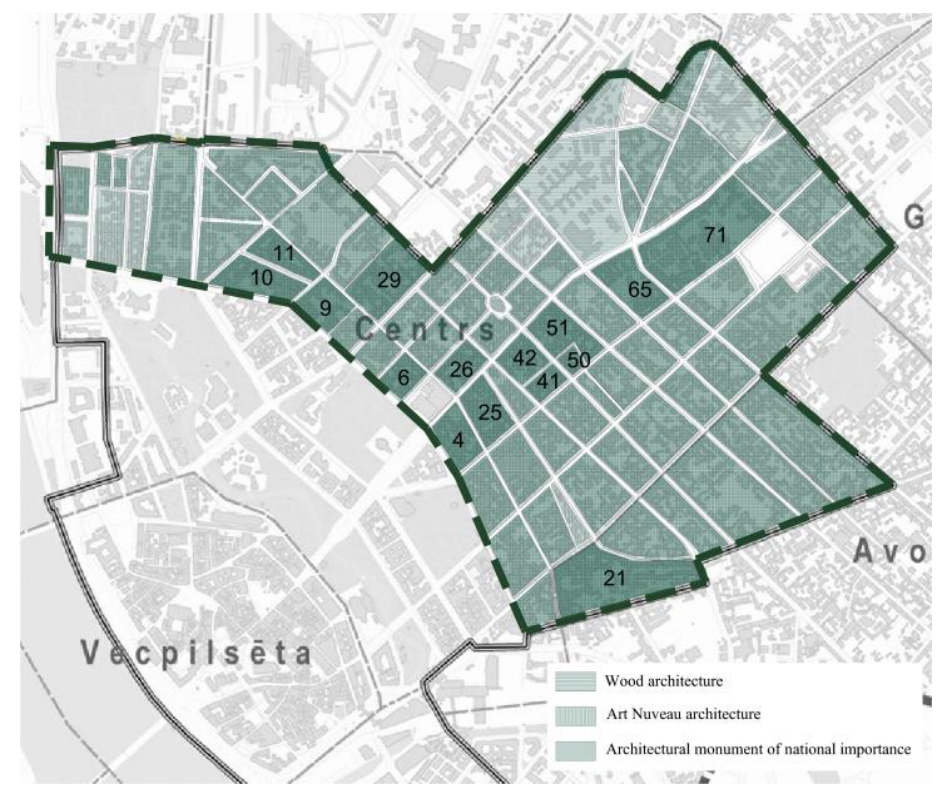

Fig. 4. Overlay map of architectural values in RHC.

Criteria. The presence of cultural heritage or buildings of high architectural value is just one component essential for habitable environment. The space between the buildings is another important component - it can upgrade if it is human-oriented or downgrade the living environment if human needs are disregarded. Jacobs [43], Whyte [44], [45] were the frontiers of the human-oriented approach in urban planning. The term liveability is introduced to describe the quality of life in living environment integrating physical and social wellbeing parameters. There are different methods of evaluating urban liveability ranging from socioeconomic oriented methods designed for expatriates, businessmen, investors, corporations to more urban planning related criteria designed for residents and city population [46]-[64]. In the scope of this study, urban planning parameters are found to be more suitable. Following the path of the human-oriented approach, influential urban design consultant Jan Ghel has defined 12 liveable city criteria divided in three categories [65], [66]:

- Protection - protection against traffic and accidents, protection against crime and 
violence and protection against unpleasant sensory experiences;

- Comfort - opportunity to walk, to stand/stay, to see, to talk, to play and exercise;

- Delight - human scale design, opportunities to enjoy local climate, and to gain positive sensory experiences - fine views, plants, trees and water presence.

RHC is a rather homogenous environment and most of these criteria are relevant to all the RHC urban blocks - some of those are developed equally well (walking opportunities and human scale for instance); some are equally disregarded (exercising opportunities).

Liveability of cities is a dynamic process - it involves a lot of participants and holds the unstable character of human decisions. Defined criteria and evaluation of urban blocks is the attempt to capture RHC situation in one moment of time. To compare building blocks following criteria are used combining cultural heritage and liveability aspects.

Table 1. “Cultural Heritage and Liveability Block” Criteria

\begin{tabular}{ll}
\hline Criteria & Definition \\
\hline Cultural heritage & \\
\hline $\begin{array}{l}\text { Cultural and } \\
\text { historical } \\
\text { significance }\end{array}$ & $\begin{array}{l}\text { Evaluates diversity of values in an urban block. RHC comprises Art nouveau and wooden } \\
\text { buildings, national and local cultural monuments, as well as buildings with a specific cultural } \\
\text { and historical value. RHC urban blocks vary in their cultural heritage capacity }\end{array}$ \\
$\begin{array}{l}\text { Variety of } \\
\text { construction } \\
\text { periods }\end{array}$ & $\begin{array}{l}\text { More construction periods show a wider spectrum of the development periods of city, believes } \\
\text { and values of different times and create richer background for further developments }\end{array}$ \\
\hline
\end{tabular}

\section{Protection}

Protection against Most important criteria for liveable cities crime and violence

Protection against unpleasant sensory experiences

Air pollution and noise problems are directly related to the intensity of the traffic of street adjacent to the urban block. More intensive streets create more pollution and noise. Blocks not directly connected to the main arteries of the city are considered more liveable despite the fact that over the years the greatest architectural achievements and treasures were on display facing the most important routes of the city

\section{Comfort}

Opportunity to stay

There are several parks at the central part of the RHC that are accessible to any urban block and sit within a walking distance ( $15 \mathrm{~min})$, but public spaces along the streets are poorly developed. None of RHC urban blocks are privileged to comprise a pedestrian street or public recreational spaces. In this criteria street cafes are recognized as an added value to the streetscape and urban environment

Landscaped courtyard

Municipal decisions to support and develop car infrastructure has led to private initiatives to explore their properties as parking lots for cars. Car infrastructure in inner spaces of urban blocks prevails over space for leisure, exercise and recreational functions. Landscaped courtyards add qualities to the urban liveability

\section{Delight}

Positive sensory experiences

Renovation cycle of buildings
Positive sensory experiences among other aspects are provided by the presence of trees, plants and water. Trees along the street add a positive sense to the urban environment

High quality Baukultur should not stop with handing the key to the owner. Not only buildings should be built following high standards but respectfully maintained as well. Jan Gehl's criteria are complemented with the criterion evaluating the condition of the buildings - are the buildings well preserved improving the environment or deteriorated degrading the environment

The weights of the criteria are obtained in a pairwise comparison matrix according to Analytical Hierarchy Process methodology [25]. Fig. 5 reflects the criteria weight. Cultural 
significance and a variety of construction periods are defined as the most important criteria for "Cultural heritage block". From the liveability perspective, the most important is protection against crime, good sensory experience and the renovation of buildings. Weighted criteria reflect the priorities of the authors.

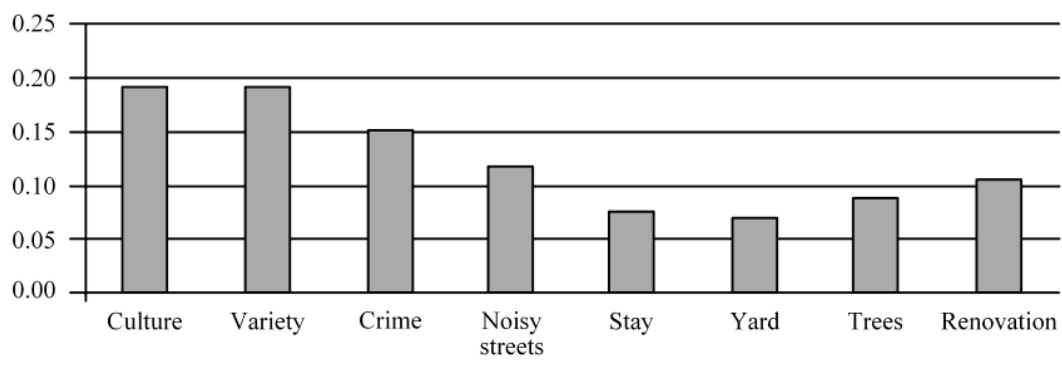

Fig. 5. Cultural heritage and liveability criteria weight.

Indicators. Each criterion is evaluated with the relevant indicator best describing the qualities and the essence of the criterion summarized in Table 2.

TABle 2. "Cultural Heritage AND LiVEability BlOCK” CRITERIA Evaluation IndiCATORS

\begin{tabular}{|c|c|}
\hline Criteria & Definition \\
\hline \multicolumn{2}{|l|}{ Cultural heritage } \\
\hline $\begin{array}{l}\text { Cultural and historical } \\
\text { significance }\end{array}$ & $\begin{array}{l}\text { For each architectural monument of national importance } 3 \text { points, } 2 \text { points for the local } \\
\text { monument and } 1 \text { point for each other building with a historical value. Specific indicator } \\
\text { was obtained dividing the total number of points by the number of plots in the block [64], } \\
\text { [67] }\end{array}$ \\
\hline $\begin{array}{l}\text { Variety of } \\
\text { construction periods }\end{array}$ & $\begin{array}{l}7 \text { construction periods were defined - 1) prior to } 1884 \text {; 2) } 1885-1923 \text {; 3)1924-1944; } \\
\text { 4) } 1945-1960 \text {; 5) } 1961-1991 \text {; 6) } 1992-2000 ; 7 \text { ) } 2001 \text { - up until nowadays. } 1 \text { point for } \\
\text { each decade of the construction period was awarded. Specific indicator was obtained } \\
\text { dividing the total number of points by number of plots in the block [68] }\end{array}$ \\
\hline \multicolumn{2}{|l|}{ Protection } \\
\hline $\begin{array}{l}\text { Protection against } \\
\text { crime and violence }\end{array}$ & $\begin{array}{l}\text { Number of crimes over last } 3 \text { years committed in urban block and adjacent streets were } \\
\text { counted. Specific indicator was obtained dividing the total number of crimes by the total } \\
\text { area of the block [69] }\end{array}$ \\
\hline $\begin{array}{l}\text { Protection against } \\
\text { unpleasant sensory } \\
\text { experiences }\end{array}$ & $\begin{array}{l}\text { Each adjacent street of the block was evaluated. } 0 \text { points if the street is a part of route of } \\
\text { national importance; } 2 \text { points for city magisterial street; } 3 \text { points for secondary street; } 4 \\
\text { points for small by-street was awarded. Specific indicator was obtained dividing the total } \\
\text { number of points by number of adjacent streets in the block [64] }\end{array}$ \\
\hline \multicolumn{2}{|l|}{ Comfort } \\
\hline $\begin{array}{l}\text { Opportunity to stay } \\
\text { and sit }\end{array}$ & $\begin{array}{l}\text { Meters of the street length occupied by seasonal street cafes bars were evaluated. Specific } \\
\text { indicator was obtained dividing the total meterage of cafes by total perimeter of the block }\end{array}$ \\
\hline Landscaped courtyard & $\begin{array}{l}\text { In the scope of this study, it was determined that publicly accessible parking lots serve the } \\
\text { cars, not the people residing in the city. Plot in an urban block comprising public parking } \\
\text { lot is penalized with }-2 \text { points. }-1 \text { point if inner courtyard serves just for cars. } 0 \text { points if } \\
\text { courtyard is left empty, with no landscaping elements. } 1 \text { point if there is vegetation in } \\
\text { courtyard with cars. } 2 \text { points landscaped courtyard without cars. Specific indicator was } \\
\text { obtained dividing the total number of points by number of plots in the block }\end{array}$ \\
\hline
\end{tabular}




\begin{tabular}{ll}
\hline Delight & \\
\hline $\begin{array}{l}\text { Positive sensory } \\
\text { experiences }\end{array}$ & $\begin{array}{l}\text { Street landscaping is evaluated in this criterion. Each adjacent street is considered }-1 \text { point } \\
\text { if there are no trees along the street and cars are occupying part of the sidewalk. } 0 \text { points if } \\
\text { there are no trees on any side of the street and cars are parked on the road. } 1 \text { point if there } \\
\text { are trees along one side of the street. 2 points if there are trees along both sides of the street. } \\
\text { Specific indicator was obtained dividing the total number of points by number of adjacent } \\
\text { streets in the block [64] } \\
\text { 0 points for abandoned and deteriorating buildings long past the necessary renovation } \\
\text { cycle; 2 points for un-renovated building closely past the renovation cycle and } 3 \text { points for } \\
\text { renovated buildings are awarded. Specific indicator was obtained dividing the total number } \\
\text { of points by number of buildings in the block }\end{array}$ \\
Renovation cycle of \\
buildings
\end{tabular}

Ranking the alternatives. There are two distinctive blocks among others. Block No. 11 and Block No. 50. First one located at a border of RHC comprises outstanding cultural heritage values - the most remarkable Art Nouveau examples in Riga Historic City. The second block ranking the highest overall ranking of alternatives from cultural heritage and liveability perspective is a small urban block in the inner part of RHC. Block No. 50 gains this predominance ranking high both in terms cultural heritage and in the top 3 in terms of liveability criteria (crime, unpleasant sensory experiences and renovation of buildings).

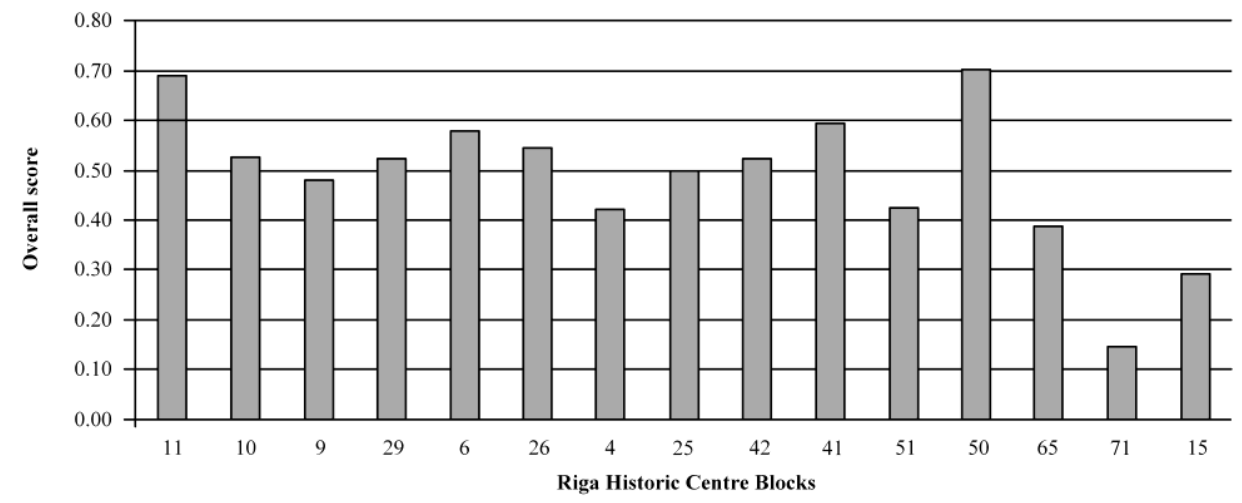

Fig. 6. Ranking the "Cultural heritage and liveability" alternatives.

\subsubsection{Multi-Criteria Analysis, Selecting the "Energy Block"}

Multi-criteria analysis goal from the energy perspective is to select the Riga Historic Center urban block with the greatest potential for transformation into a Positive Energy Block.

There are two phases for selecting the most appropriate urban block for transition to the PEB. In the first phase outranking criteria are defined. The urban block is processed for further research if: 1) there is an energy intensive enterprise located in the block; 2) the block has a residential function of at least $10 \%$; 3 there is an undeveloped plot in the urban block for highly efficient development. The medieval part of the RHC and the boulevard circle was excluded from further study since those are areas of special cultural value and distinctive character. The research area is marked with a blue dotted line (see Fig. 7). Map overlay method was used to visualize the shortlisted urban blocks. The darker the block (multiple layers) - the more qualities it carries. From the 82 RHC urban blocks in Riga Historic Centre, 12 blocks are suitable for more detailed research and multi-criteria analysis. 


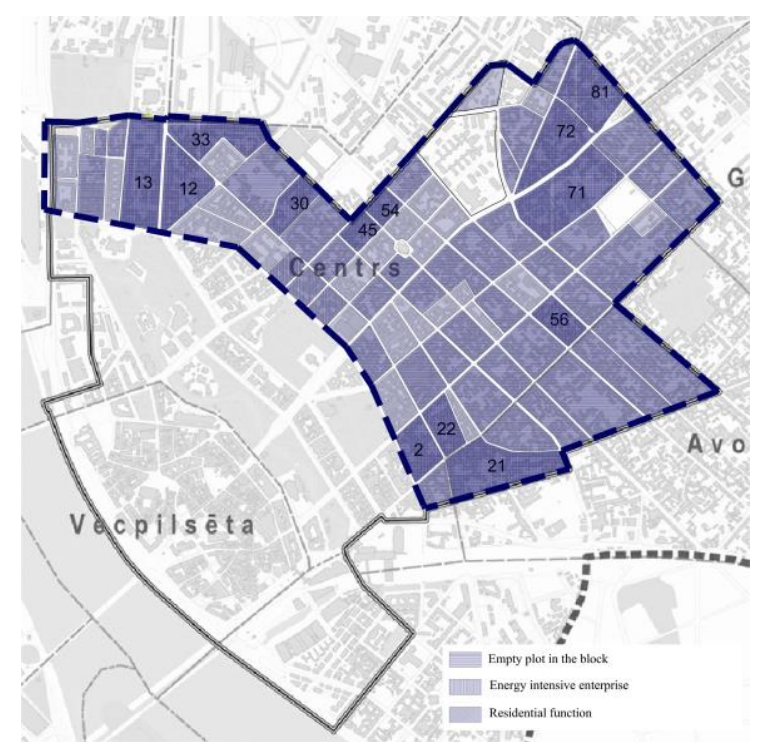

Fig. 7. Shortlisted "Energy blocks".

TABle 3. "ENERGy Block" CRITERIA

\begin{tabular}{l} 
Criteria \\
\hline Building density \\
Proportion of \\
residential function
\end{tabular}

Future development, new buildings

\section{Definition}

Density of an urban block indicates the percentage of built footprint from total area. Free area for new development would be desirable and for allocating RES technologies. High density could limit these possibilities. Low density indicates poor development of the block

It is important that residential and non-residential functions are represented in the urban block, because, typically, these functions share different times of day. If one function strongly prevails over the other, a misbalance occurs the can lead to energy demand and supply jams

Every possibility for nZEB development in PEB would lower the overall average energy demand in a block. In new development advanced energy production and exchange technologies could be widely implemented

Possible intensive refurbishment

In the historic city centre there are a number of listed buildings where energy efficiency improvement measures are limited. This criterion encounters the amount of buildings where the intensive energy efficiency driven refurbished can be applied. The more there are buildings the can be intensively refurbished - the lower the overall energy demand of the block

Energy intensive function

To develop efficient and advanced energy exchange concepts energy intensive consumer within the block is needed in PEB. Energy intensive consumer can become waste heat source and surplus energy produced should not be transmitted to the grid. There are 5 energy intensive functions recognized in RHC: 1) production; 2) data centres; 3) office buildings; 4) hotels; and 5) libraries with strict indoor climate regulation demand. Cafes, restaurants are not considered energy intensive in the scope of this study

Type of energy intensive function

Defined Energy intensive functions vary in their intensity. Since there is no energy consumption data available for each building "type of energy intensive function" estimates the differences between functions

Criteria. MCA method TOPSIS for selecting the energy block is chosen. Six criteria are defined to evaluate urban blocks and their capacities for transition to a Positive energy block. 
Criteria weights are obtained in a pairwise comparison matrix following the Analytical Hierarchy Process methodology [25]. Selected criteria are applicable worldwide in dense urban areas. Selected alternatives are local.

The most important criteria within the scope of this study are the presence of energy intensive enterprise in the urban block and its type. There are a lot of strategies widely applicable to building thermal envelope. But the energy efficiency strategies dealing with the optimization of energy exchange are the next generation in transition to Positive Energy Blocks. Therefore, criteria "Energy intensive function" and "Type of function" are strongly prevailing over the other criteria. Fig. 8 reflects the overall criteria weight. All the selected criteria are important for further study. Criteria with less significant importance in selection of urban block are the "Building density" and "Residential function".

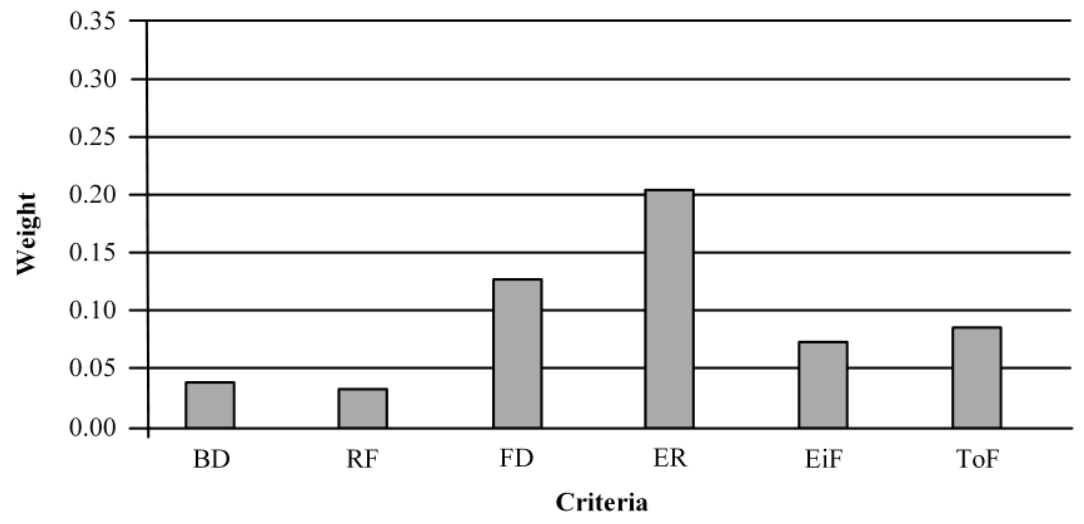

Fig. 8. "Energy block" criteria weight.

Indicators. Each criterion is evaluated with the relevant indicator best describing the qualities and the essence of criterion summarized in Table 4.

\section{TABLE 4. "ENERGY BLOCK” CRITERIA INDICATORS}

\begin{tabular}{|c|c|}
\hline Criteria & Definition \\
\hline Building density & $\begin{array}{l}\text { Building footprint is divided by the overall area of the selected block. As the optimum } 50 \% \\
\text { of building density is defined Distance from } 50 \% \text { is calculated [67]-[71] }\end{array}$ \\
\hline $\begin{array}{l}\text { Proportion of } \\
\text { residential function }\end{array}$ & $\begin{array}{l}\text { As the optimum } 50 \% \text { of residential function proportion in urban block is defined. Distance } \\
\text { from } 50 \% \text { is calculated [67]-[72] }\end{array}$ \\
\hline $\begin{array}{l}\text { Future development, } \\
\text { new buildings }\end{array}$ & $\begin{array}{l}\text { Possible new development building footprint in every plot is evaluated. Total new } \\
\text { development footprint in all plots of the block is divided by the overall area of the block [ } 73 \text { ] }\end{array}$ \\
\hline $\begin{array}{l}\text { Possible intensive } \\
\text { refurbishment }\end{array}$ & $\begin{array}{l}\text { Buildings } 1960-2000 \text { are designated for intensive energy efficiency refurbishment. Criterion } \\
\text { expressed as the building footprint divided by the overall area of the block }\end{array}$ \\
\hline $\begin{array}{l}\text { Energy intensive } \\
\text { function }\end{array}$ & $\begin{array}{l}\text { Criterion expressed as the energy intensive building footprint divided by the total area of the } \\
\text { building footprint in the block including new development }\end{array}$ \\
\hline $\begin{array}{l}\text { Type of energy } \\
\text { intensive function }\end{array}$ & $\begin{array}{l}\text { The most energy intensive function is the industrial enterprises awarded with } 5 \text { points. Less } \\
\text { intensive (and less waste heat expected) functions are data centres }-4 \text { points. Data office } \\
\text { buildings }-3 \text { points, hotels }-2 \text { points and libraries (conditioned) }-1 \text { point }\end{array}$ \\
\hline
\end{tabular}


Since the data obtained have incomparable dimensions, data normalization is carried out according to Weitendorf linear normalisation [74]. Eq. (1) for maximised values and Eq. (2) for minimised values:

$$
\begin{gathered}
b_{i j}=\frac{a_{i j}-\min _{i j}}{\max _{i j}-\min _{i j}}, \\
b_{i j}=\frac{\max _{i j}-a_{i j}}{\max _{i j}-\min _{i j}} .
\end{gathered}
$$

Ranking the alternatives. The alternative with the highest ranking (Fig. 9) is average size urban block that scored high in three most important criteria - it comprises a data centre that occupies about half of building footprint of urban block " 22 ", the type of function is the second most intensive and it carries big potential for intensive energy efficiency refurbishment. Urban block "45/54" ranking second, comprises a significant footprint of the data centre as well. Urban block "72" ranking third comprises the most intensive function - industry, but it covers proportionally less of the overall building footprint in the urban block.

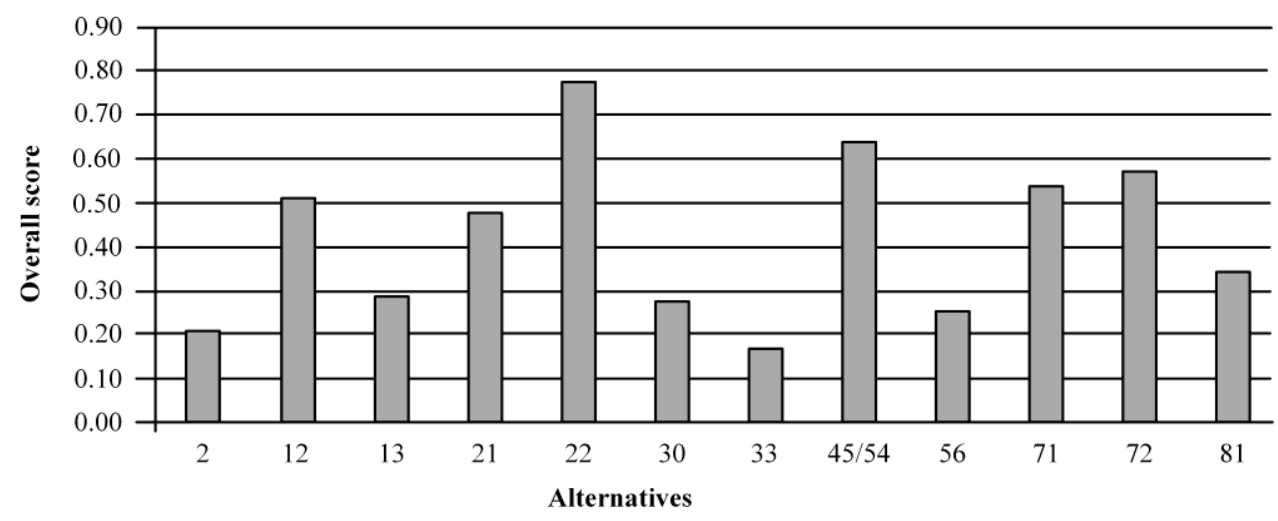

Fig. 9. Ranking "Energy block" alternatives.

\subsection{PHASE 3 - Comparison of the Results, Decision Making}

The study shows that higher quality architecture carrying more significant cultural value is concentrated in the central areas of Riga Historic Centre along the main routes, where once it had a representative function - to exhibit the technological achievements and conceptually new ideas. Unfortunately, over time the main routes have lost their role to showcase new architectural concepts and ideas and have turned into transportation infrastructure. Cars prevail over humans and the culturally most valuable areas are losing their liveability to traffic. It is found that the blocks with higher liveability capacity are located a bit away from the main streets but still in central areas of the RHC. These blocks have a lower cultural value, but higher liveability qualities. 
"Energy blocks" are mostly situated in areas at the edges of the RHC. Most of the identified energy intensive units are built after WWII. In post-war planning, public spaces where injected in the existing urban pattern. Post-war/Soviet-period buildings have not been evaluated yet, none of these buildings are listed. In outranking phase of multi-criteria analysis creating the shortlist of potential urban blocks suitable for the research only two blocks No. 21 and No. 71 were on both lists "Energy" and "Heritage". Neither of those ranked high in overall ranking of alternatives and were not discussed for further research.

Energy perspective multi-criteria analysis has highlighted urban block with significant deep decarbonisation potential. Cultural heritage and liveability MCA have highlighted two outstanding Riga Historic Centre blocks - one carrying cultural heritage values, but the other - representing urban liveability qualities. The decision has been made to select block No. 22 for Smart Urban regeneration and implement the liveability and cultural qualities of blocks No. 11 and No. 50 to create a vibrant city centre block.

\section{DISCUSSION}

In this paper an attempt of quantifying and measuring cultural heritage, urban liveability and energy efficiency potential of urban bocks is described. The proposed methodology on selecting the urban block for transition to Positive Energy Block with defined criteria adequately reflects energy efficiency potential and cultural heritage intensity and liveability qualities of urban blocks and can be used worldwide. Further steps of the launched research will be to develop: 1) intensive energy efficiency refurbishment strategies; 2) renewable energy strategies; 3 ) energy supply-demand strategies for culturally valuable urban block. In addition, further research will be to 1) implement identified urban liveability strategies within the design of the city and 2) evaluate the impact of historical heritage preservation on energy efficiency measures.

\section{ACKNOWLEDGEMENT}

This research is funded by the Ministry of Economics of the Republic of Latvia, project "Improvement of building energy efficiency technologies", project No. VPP-EM-EE-2018/1-0003.

\section{REFERENCES}

[1] Díaz S., Settele J., Brondízio E. Summary for policymakers of the global assessment report on biodiversity and ecosystem services of the Intergovernmental Science-Policy Platform on Biodiversity and Ecosystem Services. IPBES, 2019.

[2] IPCC. Global Warming of $1.5^{\circ} \mathrm{C}$. Special Report. Intergovernmental Panel on Climate Change, 2018.

[3] World Meteorological Organization. Statement on the State of the Global Climate in 2018. Geneva: WMO, 2018.

[4] Tong S., Ebi K. L. Preventing and mitigating health risks of climate change. Environmental Research 2019:174:9-13. doi:10.1016/j.envres.2019.04.012

[5] Seneviratne S. I., et al. The many possible climates from the Paris Agreement's aim of $1.5^{\circ} \mathrm{C}$ warming. Nature 2018:558:41-49. doi:10.1038/s41586-018-0181-4

[6] UNFCC. Adoption of The Paris Agreement. UNFCCC, 2015.

[7] UNFCCC. Paris Agreement. UNFCCC, 2015.

[8] ECCP. Second ECCP Progress Report. Can we meet our Kyoto targets? ECCP, 2003.

[9] A policy framework for climate and energy in the period from 2020 to 2030. Brussels: European Commission, 2014.

[10] Abergel T., Dean B., Dulac J. Global Status Report. Towards a zero-emission, efficient, and resilient buildings and construction sector. International Energy Agency, 2017.

[11] Gouldson A., et al. Exploring the economic case for climate action in cities. Global Environmental Change 2015:35:93-105. doi:10.1016/j.gloenvcha.2015.07.009 
[12] ICPP. Climate Change 2014 - IPCC Fifth Assessment Report. Intergovernmental Panel on Climate Change/Cambridge University Press. Cambridge: Cambridge University Press, 2014.

[13] Mi Z., et al. Cities: The core of climate change mitigation. Journal of Cleaner Production 2019:207:582-589. doi:10.1016/j.jclepro.2018.10.034

[14] Mata E., et al. Economic feasibility of building retrofitting mitigation potentials: Climate change uncertainties for Swedish cities. Applied Energy 2019:242:1022-1035. doi:10.1016/j.apenergy.2019.03.042

[15] Dent C. M., Bale C. S. E., Wadud Z., Voss H. Cities, energy and climate change mitigation: An introduction. Cities 2016:54:1-3. doi:10.1016/j.cities.2015.11.009

[16] Gouldson A., et al. Cities and climate change mitigation: Economic opportunities and governance challenges in Asia. Cities 2016:54:11-19. doi:10.1016/j.cities.2015.10.010

[17] Biseniece E., Freimanis R., Purvins R., Gravelsins A., Pumpurs A., Blumberga A. Study of Hygrothermal Processes in External Walls with Internal Insulation. Environmental and Climate Technologies 2018:22(1):22-41. doi:10.1515/rtuect-2018-0002

[18] Albatayneh A., Alterman D., Page A., Moghtaderi B. The Significance of Building Design for the Climate. Environmental and Climate Technologies 2018:22(1):165-178. doi:10.2478/rtuect-2018-0011

[19] Bajcinovci B., Jerliu F. Achieving Energy Efficiency in Accordance with Bioclimatic Architecture Principles. Environmental and Climate Technologies 2016:18(1):54-63. doi:10.1515/rtuect-2016-0013

[20] Davos Declaration. Presented at the Conference of Ministers of Culture, Davos, Switzerland, 2018.

[21] How to measure Baukultur - Save the Date! Presented at the International Conference on How to measure Baukultur, Geneva, Switzerland, 2019.

[22] European Commission. The Strategic Energy Technology (SET) Plan. Luxembourg: Publications Office of the European Union, 2017.

[23] European Commission. SET Plan delivering results: The Implementation Plans. Luxembourg: Publications of the European Union, 2018.

[24] European Commission. Horizon 2020. Work Programme 2018-2020. European Commission, 2018.

[25] Ishizaka A., Nemery P. Multi-Criteria Decision Analysis: Methods and Software. John Wiley \& Sons, 2013.

[26] Malczewski J. Multicriteria Analysis. Comprehensive Geographic Information Systems. Elsevier, 2018:197-217.

[27] Wang J.-J., et al. Review on multi-criteria decision analysis aid in sustainable energy decision-making. Renewable and Sustainable Energy Reviews 2009:13(9):2263-2278. doi:10.1016/j.rser.2009.06.021

[28] Tsoutsos T., et al. Sustainable energy planning by using multi-criteria analysis application in the island of Crete. Energy Policy 2009:37(5):1587-1600. doi:10.1016/j.enpol.2008.12.011

[29] Campos-Guzmán V., et al. Life Cycle Analysis with Multi-Criteria Decision Making: A review of approaches for the sustainability evaluation of renewable energy technologies. Renewable and Sustainable Energy Reviews 2019:104:343-366. doi:10.1016/j.rser.2019.01.031

[30] Baumann M., et al. A review of multi-criteria decision making approaches for evaluating energy storage systems for grid applications. Renewable and Sustainable Energy Reviews 2019:107:516-534. doi:10.1016/j.rser.2019.02.016

[31] Yang K., et al. Multi-criteria integrated evaluation of distributed energy system for community energy planning based on improved grey incidence approach: A case study in Tianjin. Applied Energy 2018:229:352-363 doi:10.1016/j.apenergy.2018.08.016

[32] Murrant D., Radcliffe J. Assessing energy storage technology options using a multi-criteria decision analysis-based framework. Applied Energy 2018:231:788-802. doi:10.1016/j.apenergy.2018.09.170

[33] Prodanuks T., Blumberga D. Methodology of municipal energy plans. Priorities for sustainability. Energy Procedia 2018:147:594-599. doi:10.1016/j.egypro.2018.07.076

[34] Trotter P. A., Cooper N. J., Wilson P. A multi-criteria, long-term energy planning optimisation model with integrated on-grid and off-grid electrification - The case of Uganda. Applied Energy 2019:243:288-312. doi:10.1016/j.apenergy.2019.03.178

[35] Centrālā statistikas pārvalde. Apdz̄ivoto mājokḷu vidējais vecums Rīgā un Jūrmalā [Online]. [Accessed 2.05.2019]. Available: $\quad$ https://www.csb.gov.lv/lv/statistika/statistikas-temas/iedzivotaji/tautas-skaitisana/meklet-tema/143apdzivoto-majoklu-videjais-vecums-riga-un (in Latvian)

[36] Šaršūne I. S. Rīgas pilsētas pašvaldības Pilsētas attīstības departamenta Pilsētvides attīstības pārvaldes Vēsturiskā centra plānošanas nodaḷa [Online]. [Accessed 2.05.2019]. Available: https://www.slideserve.com/jesse/r-gas-v-sturiskcentra-un-t-aizsardz-bas-zonas-teritorijas-pl-nojums (in Latvian)

[37] Legal Acts of Republic of Latvia. Law on Preservation and Protection of the Historic Centre of Riga [Online]. [Accessed 4.02.2019]. Available: https://likumi.lv/ta/en/en/id/76001-law-on-preservation-and-protection-of-thehistoric-centre-of-riga

[38] Rīgas domes Pilsētas attīstības departaments [Online]. [Accessed 4.02.2019]. Available: http://www.rdpad.lv/wpcontent/uploads/2014/11/ENG_STRATEGIJA.pdf (in Latvian)

[39] World Heritage Committee. Convention Concerning the Protection of the World Cultural and Natural Heritage. Report. United Nations Educational, Scientific and Cultural Organization, Naples, 1997.

[40] The International Council of Monuments and Sites. Advisory Body Evaluation (ICOMOS). UNESCO World Heritage Centre, 1996. 
[41] Bolstad P. GIS Fundamentals: A First Text on Geographic Information Systems. Acton: Eider Press, 2016.

[42] DeMers M. N. Fundamentals of Geographic Information Systems. John Wiley \& Sons, 2008.

[43] Jacobs J. The Death and Life of Great American Cities. New York: Random House, 1961.

[44] Whyte W. H. City. Rediscovering the Center. Philadelphia: University of Pennsylvania Press, 1988.

[45] Whyte W. H. The Social Life of Small Urban Spaces. New York: Project for Public Spaces Inc, 1980.

[46] The IEU. The Global Liveability Index 2018. A free overview. The Economist Intelligence Unit, 2018.

[47] Mercer. Mercer's 21st annual Quality of Living survey. Mercer, 2019.

[48] OECD. How's Life? 2017. Measuring Wellbeing. Paris: OECD Publishing, 2017.

[49] Marshall W. E. An evaluation of livability in creating transit-enriched communities for improved regional benefits. Research in Transportation Business \& Management 2013:7:54-68. doi:10.1016/j.rtbm.2013.01.002

[50] Ding X., et al. An inclusive model for assessing the sustainability of cities in developing countries Trinity of Cities' Sustainability from Spatial, Logical and Time Dimensions (TCS-SLTD). Journal of Cleaner Production 2015:109:6275. doi:10.1016/j.jclepro.2015.06.140

[51] Marsal-Llacuna L.-M., Colomer-Llinàs J., Meléndez-Frigola J. Lessons in urban monitoring taken from sustainable and livable cities to better address the Smart Cities initiative. Technological Forecasting \& Social Change 2015:90(B):611-622. doi:10.1016/j.techfore.2014.01.012

[52] Norouzian-Maleki S., Bell S., Hosseini S.-B., Faizi M. Developing and testing a framework for the assessment ofneighbourhood liveability in two contrasting countries: Iran and Estonia. Ecological Indicators 2015:48:263-271. doi:10.1016/j.ecolind.2014.07.033

[53] Silva A. N. R., et al. A comparative evaluation of mobility conditions in selected cities of the five Brazilian regions. Transport Policy 2015:37:147-156. doi:10.1016/j.tranpol.2014.10.017

[54] Zanella A., Camanho A. S., Dias T. G. The assessment of cities' livability integrating human wellbeing and environmental impact. Annuals of Operations Research 2015:226(1):695-726. doi:10.1007/s10479-014-1666-7

[55] Zhou J., Shen L., Song X., Zhang X. Selection and modeling sustainable urbanization indicators: A responsibilitybased method. Ecological Indicators 2015:56:87-95. doi:10.1016/j.ecolind.2015.03.024

[56] Zhan D., et al. Assessment and determinants of satisfaction with urban livability in China. Cities 2018:79:92-101. doi:10.1016/j.cities.2018.02.025

[57] Reis I. F. C., et al. An evaluation thermometer for assessing city sustainability and livability. Sustainable Cities and Society 2019:47:101449. doi:10.1016/j.scs.2019.101449

[58] Kashef M. Urban livability across disciplinary and professional boundaries. Frontiers of Architectural Research 2016:5(2):239-253. doi:10.1016/j.foar.2016.03.003

[59] Okulicz-Kozaryn A. City life: Rankings (livability) versus perceptions (satisfaction). Social Indicators Research 2013:110(2):433-451. doi:10.1007/s11205-011-9939-x

[60] Faria P. A. M., et al. Combining cognitive mapping and MCDA for improving quality of life in urban areas. Cities 2018:78:116-127. doi:10.1016/j.cities.2018.02.006

[61] PPS (Project for Public Spaces). How to Turn a Place Around. New York: Project for Public Spaces Inc, 2000.

[62] Ghasemi K., Hamzenejad M., Meshkini A. The spatial analysis of the livability of 22 districts of Tehran Metropolis using multi-criteria decision making approaches. Sustainable Cities and Society 2018:38:382-404. doi:10.1016/j.scs.2018.01.018

[63] Stanislav A., Chin J. T. Evaluating livability and perceived values of sustainable neighborhood design: New Urbanism and original urban suburbs. Sustainable Cities and Society 2019:47:101517. doi:10.1016/j.scs.2019.101517

[64] Yassin H. H. Livable city: An approach to pedestrianization through tactical urbanism. Alexandria Engineering Journal 2019:58(1):251-259. doi:10.1016/j.aej.2019.02.005

[65] Ghel J. Cities for People. Washington: Island Press, 2010.

[66] Ghel J. Life Between Buildings: Using Public Space. Washington:Island Press, 2011.

[67] Riga Municipality City Development Department. Historic Centre of Riga urban planning documentation graphical annexes [Online]. [Accessed 4.02.2019]. Available: http://www.rdpad.lv/rtp/rvc/

[68] Rīgas Jūgendstila centrs. Jūgendstila arhitektūras objekti Rīgā [Online]. [Accessed 8.03.2019]. Available: http://www.jugendstils.riga.lv/lat/JugendstilsRiga (in Latvian)

[69] Latvijas Ģeotelpiskās informācijas aǵentūra. Karšu Pārlūks [Online]. [Accessed 8.03.2019]. Available: https://kartes.lgia.gov.lv/karte/ (in Latvian)

[70] Kultūrvēsturiskie ansambḷi un kultūras pieminekḷi RVC un tā aizsardzības zonā. Rīgas domes Pilsētas attīstības $\begin{array}{lllll}\text { departaments } \quad \text { [Online]. } & \text { [Accessed } 03.2019]\end{array}$ content/uploads/2014/12/11_Pieminekli_6000_konsolidets_042017.pdf (in Latvian)

[71] Riga Municipality City Development Department GIS information.

[72] The Information Centre of the Ministry of the Interior. Registered criminal offenses on a digital map (GIS) [Online]. [Accessed 25.04.2019]. Available: http://www.ic.iem.gov.lv/gis/index.php

[73] State Land Service of the Republic of Latvia [Online]. [Accessed 2.05.2019]. Available: https://www.kadastrs.lv/\#

[74] Migilinskas D., Ustinovichius L. Normalisation in the selection of construction. Management and Decision Making 2007:8:297-313. doi:10.1504/IJMDM.2007.013422 